\title{
Assessment of Carbonaceous Aerosols at Mount Tai, North China: Secondary Formation and Regional Source Analysis
}

\author{
Na Zheng ${ }^{1,2}$, Shanjun Song ${ }^{3 * *}$, Xinglong Jin ${ }^{1,2}$, Hongyan Jia ${ }^{1,2}$, Yan Wang ${ }^{4}$, Yaqin $\mathrm{Ji}^{5}$, \\ Liqiong Guo ${ }^{6}$, Penghui $\mathrm{Li}^{1,2}$ \\ ${ }^{1}$ School of Environmental Science and Safety Engineering, Tianjin University of Technology, Tianjin 300384, China \\ ${ }^{2}$ Tianjin Key Laboratory of Hazardous Waste Safety Disposal and Recycling Technology, Tianjin 300384, China \\ ${ }^{3}$ National Institute of Metrology, Beijing 100029, China \\ ${ }^{4}$ School of Environmental Science and Engineering, Shandong University, Shandong 250100, China \\ ${ }^{5}$ College of Environmental Science and Engineering, Nankai University, Tianjin 300071, China \\ ${ }^{6}$ Department of Occupational and Environmental Health, School of Public Health, Tianjin Medical University, Tianjin \\ 300070, China
}

\begin{abstract}
To understand the concentrations, secondary organic aerosols (SOA) formation and source characteristics of carbonaceous aerosols in the regional environment of North China, a total of 48 fine particulate matter $\left(\mathrm{PM}_{2.5}\right)$ samples were collected at the top of Mount Tai in the summer of 2015. Organic carbon (OC) and element carbon (EC) were analyzed and resolved into eight carbonaceous species using an Organic/Elemental Carbon Analyzer following the IMPROVE thermal-optical reflectance (TOR) protocol. OC and EC mass concentrations were $4.42 \pm 3.04$ and $1.58 \pm 0.92 \mu \mathrm{g} \mathrm{m}^{-3}$, respectively, which were much higher than that of other domestic or abroad observation sites. Carbonaceous aerosols showed weekday-high trend during sampling period, which can be partly explained by anthropogenic effects. Higher concentrations of secondary organic carbon (SOC) were estimated by EC-tracer method during cloud/fog processing, indicating the fact that aqueousphase reaction in droplets was an important pathway for SOC formation. Two source analysis approaches, consisting of Potential Source Contribution Function (PSCF) and Positive Matrix Factorization (PMF) were adopted to identify the regional sources and emission sources of carbonaceous species, and the apportion contributed by these sources. PSCF result demonstrated that the potential regional sources in the northwest, southwest and east coastal areas of Mount Tai contributed significantly to carbonaceous species loading in $\mathrm{PM}_{2.5}$. Additionally, three main emission sources were identified according to PMF result: diesel vehicle exhaust, biomass burning and mixed sources of gasoline vehicle exhaust and coal combustion, and each of sources had an average contribution of $26.4 \%, 19.0 \%$ and $54.5 \%$ to carbonaceous aerosols, respectively.
\end{abstract}

Keywords: $\mathrm{PM}_{2.5}$; Carbonaceous species; Regional environment; Long-range transport; Source apportionment.

\section{INTRODUCTION}

Carbonaceous aerosol is a common component and account for $10 \%$ to $70 \%$ of fine particulate matter $\left(\mathrm{PM}_{2.5}\right)$ (Turpin et al., 2000). In general, carbonaceous aerosol consists of three main fractions: namely elemental carbon (EC, also called black carbon, BC), organic carbon (OC)

\footnotetext{
* Corresponding author.

Tel./Fax: 862260214203

E-mail address: lipenghui406@163.com

** Corresponding author.

Tel./Fax: 01064524787

E-mail address: songsj@nim.ac.cn
}

and carbonate carbon (CC) (Martinsson et al., 2017). EC is primarily generated from incomplete combustion processes of anthropogenic sources including fossil fuel combustion and biomass burning. OC is either directly emitted from combustion processes to ambient atmosphere or formed during gas to particle conversion process by photochemical reaction of organic volatile precursors. Therefore $\mathrm{OC}$ is a complicated organic mixture of multiple substances, which can be classified into primary organic carbon (POC) and secondary organic carbon (SOC). CC, typically found in coarse particle fractions of demolition or building dust and natural mineral dust, was always ignored in many studies on fine particles (Thuy et al., 2018).

Carbonaceous aerosol has many adverse effects on both environmental safety and human health, such as reducing visibility, affecting global climate and causing a variety of 
human diseases, making it a hot topic in modern atmospheric environment research (Xu et al., 2018). OC, together with EC, can scatter lights and have impacts on cloud optical properties, resulting in the imbalance of the global radiation, which in turn affects the global and regional climates via direct or indirect radiative forcing (Zhao et al., 2013). Once the positive radiation from polluted air is forced to dominate, the global average surface temperature will rise. OC, EC and their mixture with inorganic compositions can also lead to the deterioration of air and reduced visibility ( $\mathrm{Ji}$ et al., 2017). Meanwhile, because of the existence of polar functional groups such as carboxyl, numerous organic substances in carbonaceous aerosols can dissolve in water, and subsequently help the particles form cloud condensation nuclei $(\mathrm{CCN})$, giving rise to increased cloud optical thickness and higher reflectance of cloud, as well as stronger monsoon and rainfall patterns (Ji et al., 2018; Panicker et al., 2018). In addition, some epidemiological studies have shown that the deterioration of cardiovascular disease is closely related to human exposure to these atmospheric pollutants by comparing the trend of $\mathrm{OC}$ and EC levels with cardiovascular diseases' morbidity and mortality (Chow et al., 2006; Mauderly and Chow, 2008).

Up till now, most of the studies focusing on investigating the pollution regulation of carbonaceous aerosols have be carried out in urban, suburban or more developed industrial areas. For example, in China, a considerable amount of researches have been done in the Pearl River Delta Region (PRDR) (Fan et al., 2017), Yangtze River Delta Region (YRDR) (Chang et al., 2017), Beijing-Tianjin-Hebei (BTH) region (Zhao et al., 2013), and so on. Relatively few works have been done on the source apportionment and longrange transport of carbonaceous aerosols in the regional environment such as remote areas and high-altitude mountains. In addition, the partitioning of $\mathrm{OC}$ in atmosphere to POC and SOC has been problematic. A modeling study using a series of semi-continuous measured data obtained at the summit of Mount Tai showed that the contribution of SOC to total organic carbon (TOC) estimated by multiple regression model were $57.3 \%$ and $71.2 \%$ in spring and summer, respectively (Wang et al., 2012). In contrast, another study at Mount Tai reported a lower SOC/TOC value of $52.4 \%$, reflecting a certain deviation of SOC levels between multiple studies (Boreddy et al., 2017). This SOC uncertainty between above two studies revealed that there will be some missing emission sources or formation processes (e.g., atmospheric aqueous-phase production) of SOC in the troposphere (Youn et al., 2013). Thus, continuously investigating the aerosol sources and SOC formation mechanisms in high-altitude mountain areas is very necessary.

To address the issues mentioned above, the $\mathrm{PM}_{2.5}$ samples were collected from June to August, 2015 at the top of Mount Tai. Mount Tai is located in the North China Plain. This region is one of the most developed areas of China, with the highest anthropogenic carbonaceous aerosols emissions (Zhang et al., 2009). Mount Tai, the highest mountain here, can provide a unique place to reflect the atmospheric processes, diffusion and long-range transport pattern of air pollutants in the North China Plain. Moreover, given that weather conditions in mountain areas are more complicated than those in urban and industrial areas, the atmospheric processes about secondary organic aerosols (SOA) formation during cloud/fog event and precipitation scavenging during rain period can be analyzed to study meteorological effects.

In this study, we conducted a field measurement of carbonaceous species at Mount Tai. The purposes of this study are (1) to investigate the concentrations of OC and EC at the regional background site, (2) to evaluate the formation of SOC during sampling period, and (3) to understand the source distribution and long-range transport of targeted pollutants at Mount Tai.

\section{MATERIALS AND METHODS}

\section{Sampling Campaign}

From June 15 to August 11, 2015, sampling campaign of $\mathrm{PM}_{2.5}$ was conducted at Taishan meteorological station built at the top of Mount Tai $\left(117.10^{\circ} \mathrm{E}, 36.25^{\circ} \mathrm{N}, 1532.7 \mathrm{~m}\right.$ a.s.1.), an ideal background site with small population and less pollutant emission located in central Shandong province (Fig. 1). A total of 48 samples were collected after excluding invalid sampling days due to loss of samples or sampling records during the observation period. The details of sampling followed a published method in previous study (Liu et al., 2017). Briefly, a high-volume air sampler (HI-Q 7386, HI-Q Environmental Products Company, Inc. San Diego, CA, USA) operating at the sampling flow rate of $1000 \mathrm{~L} \mathrm{~min}{ }^{-1}$ was used to collect $\mathrm{PM}_{2.5}$ samples. The particle phase samples were collected using quartz fiber filters (QFF, $203 \times 254 \mathrm{~mm}$, Munktell, Sweden), which was pre-baked at $450^{\circ} \mathrm{C}$ for 6 hours to remove organic residues. To correct the artifacts, field blanks were also set during sampling campaign. Prior to sampling, all quartz filters were equilibrated for 24 hours under constant temperature and relative humidity $\left(25^{\circ} \mathrm{C}, 55 \%\right)$ conditions, and then weighed and stored in a $4^{\circ} \mathrm{C}$ refrigerator for further use. After sampling, the samples were weighed once again to obtain the dust weigh, wrapped in aluminum foil, sealed in plastic zip lock bags, and then stored in a freezer at $-20^{\circ} \mathrm{C}$ for instrumental analysis.

\section{Instrumental Analysis}

Concentrations of OC, EC and corresponding components were analyzed using an Organic/Elemental Carbon Analyzer (DRI model 2001, Atmoslytic Inc. USA) based on the IMPROVE thermal-optical reflectance (TOR) protocol for pyrolysis correction. A $0.526 \mathrm{~cm}^{2}$ punch of each filter was analyzed under different temperatures to separate different carbonaceous species (i.e., $\mathrm{OC} 1\left(140^{\circ} \mathrm{C}\right), \mathrm{OC} 2\left(280^{\circ} \mathrm{C}\right)$, OC3 $\left(480^{\circ} \mathrm{C}\right)$ and $\mathrm{OC} 4\left(580^{\circ} \mathrm{C}\right)$ in the absence of nonoxidizing helium, and $\mathrm{EC} 1\left(580^{\circ} \mathrm{C}\right), \mathrm{EC} 2\left(740^{\circ} \mathrm{C}\right)$ and $\mathrm{EC} 3$ $\left(840^{\circ} \mathrm{C}\right)$ under the oxidizing gas of helium with $2 \%$ oxygen). Some OC could pyrolyze to EC when it was filled with the inert helium during heating process, which was named as optically pyrolyzed carbon (OPC) (Zhang et al., 2018). Therefore, OC was represented as the sum of OC1, OC2, 


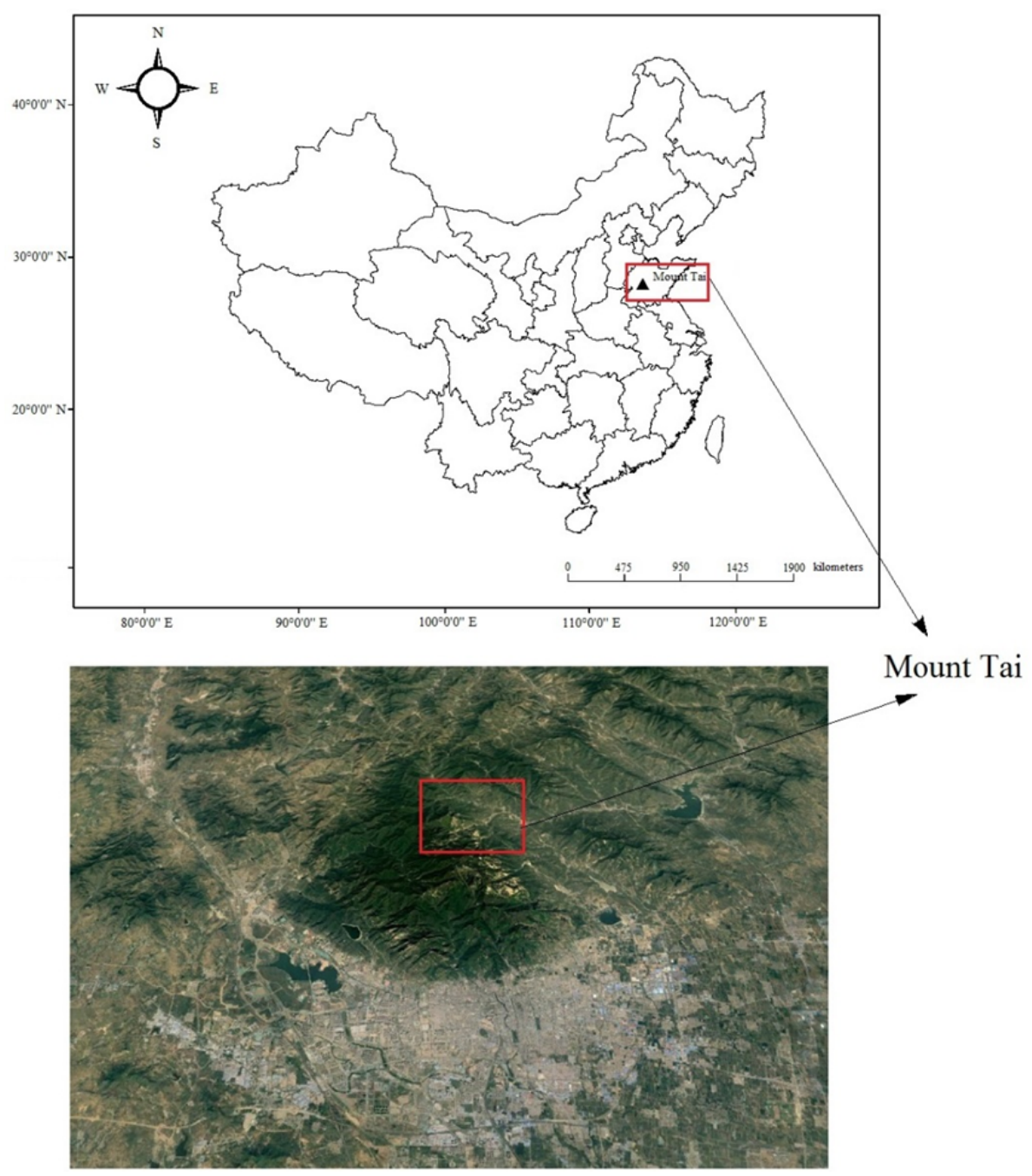

Fig. 1. Location of the sampling site on the top of Mount Tai.

OC3, OC4 and OPC, and EC was expressed as the sum of EC1, EC2 and EC3 minus OPC following TOR protocol.

\section{Positive Matrix Factorization (PMF) Model}

PMF receptor model proposed by Paatero and Tapper (1993) can be adopted to identify main emission sources of pollutants and evaluate their contributions to different species. In recent years, PMF model was widely used in the source apportionment study of air and soil pollutants, showing good applicability in the field of environment science (Xu et al., 2016; Li et al., 2018). The analytical procedure of PMF is to decompose a sample data matrix (X) into two related matrices: source profile (f) and source contribution $(\mathrm{g})$ and the principle of model can be briefly described as following expression (Liu et al., 2018):

$X_{i j}=\sum_{k=1}^{p} g_{i k} f_{k j}+e_{i j}$

where $p$ is the number of emission sources, $g_{i k}$ is the contribution of emission source $k$ to sample $i$ and $f_{k j}$ is the source profile of species $\mathrm{j}$ from source $\mathrm{k}$. $\mathrm{X}_{\mathrm{ij}}$ and $\mathrm{e}_{\mathrm{ij}}$ represent the concentration and residual error of species $j$ measured in sample i, respectively.

PMF model provides a solution for the purpose to minimize the objective function Q (Eq. (2)), based on an uncertainty $(\mathrm{u})$ for each measurement (Manousakas et al., 2017).

$Q=\sum_{i=1}^{m} \sum_{j=1}^{n}\left[\frac{X_{i j}-\sum_{k=1}^{p} g_{i k} f_{k j}}{u_{i j}}\right]^{2}$

where $Q$ is a defined objective function for obtaining optimal matrices $\mathrm{f}$ and $\mathrm{g}, \mathrm{m}$ and $\mathrm{n}$ are the quantity of target pollutant species and samples, respectively, and $\mathrm{u}_{\mathrm{ij}}$ represents the uncertainty of species $j$ in sample $i$, which can be calculated based on sampling errors, invalid data and outliers, as well as method detection limit (MDL).

In this study, source apportionment software EPA PMF (Version 5.0.14) was applied for our analysis and operating details can be found in EPA PMF 5.0 User Guide (U.S. 
EPA, 2014). The input data files consist of two parts of concentration data and uncertainty data for carbonaceous species, which has been arranged before analysis. Two-six factors were examined to obtain a reasonable number of emission sources. The fitting result with minimal Q value was selected as optimization solution for explaining the source profiles and contributions to eight carbonaceous species.

\section{Potential Source Contribution Function (PSCF) Analysis}

PSCF model was often employed to determine potential regional sources of target pollutants. PSCF value for each grid cell represents the probability that the air mass arriving at observation site has a contributed concentration exceeding an arbitrarily set criterion. The PSCF values for grid cells are calculated by following equation (Li et al., 2017):

$\operatorname{PSCF}_{\mathrm{ij}}=\mathrm{W}_{\mathrm{ij}} \times\left(\mathrm{m}_{\mathrm{ij}} / \mathrm{n}_{\mathrm{ij}}\right)$

where $\mathrm{i}, \mathrm{j}$ represents the determination parameter of grid cell azimuth, $\mathrm{n}_{\mathrm{ij}}$ are the total number of concentration points loading in the grid cell $(i, j), m_{i j}$ is the number of concentration points exceeding pre-defined threshold value in this grid cell, and $\mathrm{W}_{\mathrm{ij}}$ is an arbitrary weight function aiming to reduce the uncertainties of PSCF results.

In this study, the PSCF analysis was simulated by air mass trajectory statistics software TrajStat (Version 1.2.2.6). The grid cell size was customized by the software. Meanwhile, the $75^{\text {th }}$ percentile concentrations for each species were selected to define the threshold values mentioned above (Bressi et al., 2014). $\mathrm{W}_{\mathrm{ij}}$ was assigned as:

$$
\mathrm{W}_{\mathrm{i}, \mathrm{j}}= \begin{cases}1.00 & \mathrm{n}_{i j}>3 \mathrm{n}_{a v e} \\ 0.70 & 1.5 \mathrm{n}_{a v e}<\mathrm{n}_{i j} \leq 3 \mathrm{n}_{a v e} \\ 0.42 & \mathrm{n}_{a v e}<\mathrm{n}_{i j} \leq 1.5 \mathrm{n}_{a v e} \\ 0.17 & 0<\mathrm{n}_{i j} \leq \mathrm{n}_{a v e}\end{cases}
$$

\section{RESULTS AND DISCUSSION}

\section{OC and EC Concentrations}

The measured levels of carbonaceous components at Mount Tai during sampling campaign were presented in
Table 1. The daily concentrations of $\mathrm{OC}$ and $\mathrm{EC}$ varied from 1.06 to $14.8 \mu \mathrm{g} \mathrm{m}^{-3}$ and 0.31 to $3.83 \mu \mathrm{g} \mathrm{m}^{-3}$ with the average of $4.42 \pm 3.04$ and $1.58 \pm 0.92 \mu \mathrm{g} \mathrm{m}^{-3}$, respectively. The OC and EC concentrations loading in $\mathrm{PM}_{2.5}$ in our study were higher than the seasonal-average concentrations observed at Mount $\mathrm{Abu}$ in western India (2.2 and $0.2 \mu \mathrm{g} \mathrm{m}^{-3}$ ) and the background concentrations measured at Mount Jiuxian in Southeast China (2.03 and $0.07 \mu \mathrm{g} \mathrm{m}^{-3}$ ) (Ram et al., 2008; Niu et al., 2013). A field study conducted at rural sites of New York has also reported lower OC and EC

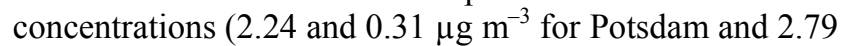
and $0.36 \mu \mathrm{g} \mathrm{m}^{-3}$ for Stockton) than that of our study (Sunder Raman et al., 2008). Considering limited carbonaceous aerosol emissions in background sites, higher concentrations at Mount Tai may reflect the important role of long-range transport of pollutants from surrounding regions.

OC and EC averagely accounted for $11.1 \%$ and $4.0 \%$ of total measured $\mathrm{PM}_{2.5}$ concentration, respectively, and total carbon (TC; the sum of OC and EC) accounted for $15.1 \%$ of $\mathrm{PM}_{2.5}$. Compared to a recent study reported that the percentage of TC loading in $\mathrm{PM}_{2.5}$ was $22.7 \%$ in Beijing, $\mathrm{TC} / \mathrm{PM}_{2.5}$ ratio was lower in the present study, showing relatively less carbonaceous aerosol pollution in background environment than in urban areas (Ji et al., 2018). The mean contribution of OC to TC was found to be $72.9 \pm 7.4 \%$ during observation period, suggesting that $\mathrm{OC}$ is the more predominant contributor of carbonaceous aerosols than EC, which was consistent with the results in previous studies (Yao et al., 2016; Liang et al., 2017; Li et al., 2018).

\section{Weekday-weekend Pattern}

Several researches have proposed the viewpoint that weekly variation of carbonaceous aerosols could reflect the effects from anthropogenic activities, such as traffic and cooking emissions. For example, a short-term study reported significant differences in OC and EC levels between weekdays and corresponding weekends (Stone et al., 2008). $\mathrm{Yu}$ et al. (2009) found that the loadings of OC and EC mass concentrations between weekdays and weekends could be affected by different traffic patterns. Xu et al. (2018) presented that more residential cooking on weekends could contribute to the organic precursors, resulting in SOC formation.

Table 1. Statistical information of the daily concentrations of $\mathrm{PM}_{2.5}, \mathrm{OC}, \mathrm{EC}$ and relative ratios during June 15 to August 11, 2015 at the top of Mount Tai.

\begin{tabular}{|c|c|c|c|c|c|c|}
\hline & $\mathrm{N}^{a}$ & $\min$ & $\max$ & median & mean & $\mathrm{SD}^{b}$ \\
\hline $\mathrm{PM}_{2.5}\left(\mu \mathrm{g} \mathrm{m}^{-3}\right)$ & 54 & 2.98 & 126 & 34.9 & 44.5 & 30.5 \\
\hline $\mathrm{OC}\left(\mu \mathrm{g} \mathrm{m}^{-3}\right)$ & 48 & 1.06 & 14.8 & 3.49 & 4.42 & 3.04 \\
\hline $\mathrm{EC}\left(\mu \mathrm{g} \mathrm{m}^{-3}\right)$ & 48 & 0.31 & 3.83 & 1.39 & 1.58 & 0.92 \\
\hline $\mathrm{TC}\left(\mu \mathrm{g} \mathrm{m}^{-3}\right)$ & & 1.46 & 17.6 & 4.87 & 5.91 & 3.80 \\
\hline $\mathrm{OC} / \mathrm{EC}$ & & 0.96 & 7.53 & 2.76 & 2.98 & 1.21 \\
\hline OC/TC (\%) & & 48.9 & 88.3 & 73.4 & 72.9 & 7.4 \\
\hline $\mathrm{OC} / \mathrm{PM}_{2.5}(\%)$ & & 2.5 & 65.8 & 8.0 & 11.1 & 10.5 \\
\hline $\mathrm{EC} / \mathrm{PM}_{2.5}(\%)$ & & 1.0 & 19.2 & 2.7 & 4.0 & 3.6 \\
\hline $\mathrm{TC} / \mathrm{PM}_{2.5}(\%)$ & & 3.5 & 85.0 & 11.8 & 15.1 & 13.5 \\
\hline
\end{tabular}

\footnotetext{
${ }^{a}$ Valid samples number.

${ }^{b}$ Standard deviation.
} 
In the present study, concentration comparisons of OC, EC and TC between weekdays, weekends and the whole weeks were obtained and displayed in Fig. 2. Generally, weekly variations of carbonaceous aerosols showed weekdayhigh trend during sampling period, which was in agreement with a field study recorded high levels of OC and EC on weekdays in central Athens (Grivas et al., 2012). According to a report on weekday-weekend patterns, we assumed that the reduction of anthropogenic activities on weekends was the primary cause influencing OC and EC emissions (Pongpiachan et al., 2015). Though anthropogenic emissions at Mount Tai were limited, the long-range transport of pollutants appeared to be one of the most important contributors on weekdays (Zhang et al., 2014). The overall concentration decline for OC $(37.2 \%)$ on weekends was more pronounced than for EC $(20.8 \%)$, which was consistent with the significant decrease in total travel time of domestic gasoline vehicles on weekends (Villalobos et al., 2015).

Nevertheless, many studies showed that there seemed to be no uniform pattern of weekday-weekend effects on carbonaceous aerosols. It was found that OC and EC concentrations exhibited different weekly patterns in four seasons of the year (Xu et al., 2018), and additionally, an observation conducted in a big city of Shanghai revealed that local emission sources of carbonaceous aerosols didn't differ dramatically between weekdays and weekends due to the heavy traffic on weekends as well (Chang et al., 2017). For the purpose of understanding the mechanism influencing carbonaceous aerosol levels on weekdays and weekends, more works should be conducted in the future.

\section{SOA Formation}

\section{Estimation of SOC Level}

As reported previously, EC is a primary substance. OC can be derived from both primary emission together with
$\mathrm{EC}$ and secondary formation such as photochemical reaction, aqueous-phase production and heterogeneous reaction of organic precursors. Thus OC/EC ratios can identify the relative contribution of primary and secondary sources of carbonaceous aerosols. Briefly, atmospheric aerosols dominated by SOA are characterized by higher OC/EC ratios (OC/EC > 2.0) (Peng et al., 2018). In our study, $\mathrm{OC} / \mathrm{EC}$ ratios during sampling campaign were in the range of 0.96-7.53 with overall average value of $2.98 \pm 1.21$ at Mount Tai, and the ratio of more than $83 \%$ of the days exceeded 2.0, demonstrating a dominance of SOA to atmospheric aerosols.

Numerous methods have been developed to estimate SOC concentrations, such as SOC formation model (Pandis et al., 1992), emission and dispersion model (Harley and Cass, 1995) and EC-tracer method (Turpin and Huntzicker, 1991). Given that EC is mainly emitted from incomplete combustion processes and shows weak ability for chemical transformation in the air, it is an ideal tracer of primary emissions. In this study, EC-tracer method was chosen to distinguish POC and SOC, and their concentrations can be calculated using the following equations (Grivas et al., 2012):

$\mathrm{OC}=\mathrm{POC}+\mathrm{SOC}$

$\mathrm{POC}=\mathrm{EC} \times(\mathrm{OC} / \mathrm{EC})_{\mathrm{pri}}$

$\mathrm{SOC}=\mathrm{OC}-\mathrm{POC}=\mathrm{OC}-\mathrm{EC} \times(\mathrm{OC} / \mathrm{EC})_{\mathrm{pri}}$

where $\mathrm{OC}$ is the total organic carbon measured at Mount Tai, $(\mathrm{OC} / \mathrm{EC})_{\text {pri }}$ is an estimated $\mathrm{OC} / \mathrm{EC}$ ratio representing primary emissions.

The primary $\mathrm{OC} / \mathrm{EC}$ ratio may vary temporally due to the differences of meteorology and source conditions (Plaza et al., 2011). Initially, the emission inventories was

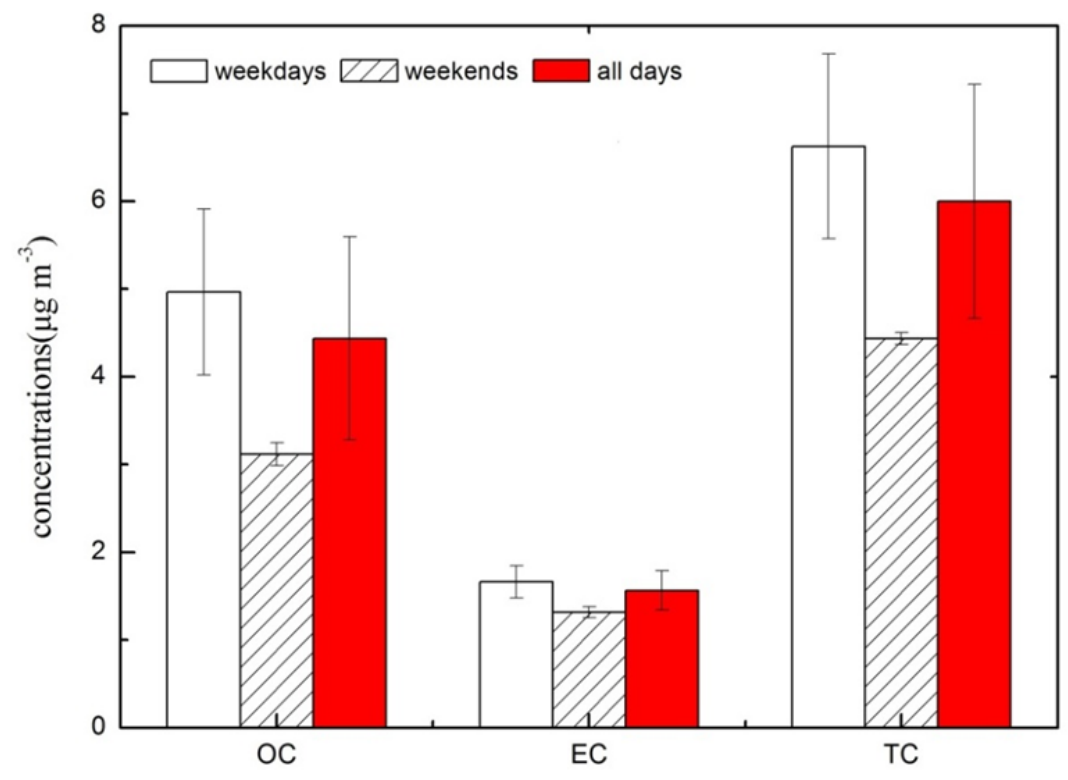

Fig. 2. Weekly concentrations of OC, EC and TC on weekdays, weekends and the whole weeks. The error bars represent standard deviation. 
employed to estimate this ratio. Later researches reported the approach that minimum $\mathrm{OC} / \mathrm{EC}$ ratio could be representative of $(\mathrm{OC} / \mathrm{EC})_{\text {pri }}$ value and the possibility of extracting (OC/EC) $)_{\text {pri }}$ using OC-EC dataset according to a regression method (Castro et al., 1999; Turpin and Huntzicker, 1991). Considering the application limitations of these methods (Grivas et al., 2012), in our study, the SOC concentrations were obtained from the regression equation built by Turpin and Huntzicker (1991):

$\mathrm{SOC}=\mathrm{OC}-\mathrm{POC}=\mathrm{OC}-(\mathrm{a} \times \mathrm{EC}+\mathrm{b})$

where a is the slope representing primary combustion ratio, $\mathrm{b}$ is intercept representing the sum of all non-combustion POC, and they can be determined by least square regression using the data with $\mathrm{OC} / \mathrm{EC}$ ratios in the lowest 5-20\% (Cao et al., 2007). The sample data with the lowest $10 \%$ ratios and without remarkable impacts of fog and cloud were selected to calculate primary OC/EC ratio. In this way, the values of a and b were selected, and the fitted least square regression line of the data mentioned above suggested that the $(\mathrm{OC} / \mathrm{EC})_{\text {pri }}$ values were $1.58,1.65$ times the result of minimum $\mathrm{OC} / \mathrm{EC}$ ratio method, indicating the uncertainty of different calculation methods of $(\mathrm{OC} / \mathrm{EC})_{\mathrm{pri}}$.

The overall SOC concentrations were $0.16-10.4 \mu \mathrm{g} \mathrm{m}^{-3}$ with the average of $2.06 \mu \mathrm{g} \mathrm{m}^{-3}$. SOC/OC ratios varied from $2.9 \%$ to $79.0 \%$ with average contribution of $43.2 \%$. SOC concentrations at daytime and nighttime during this period were 2.21 and $1.32 \mu \mathrm{g} \mathrm{m}^{-3}$, accounting for $46.7 \%$ and $39.7 \%$ of total OC respectively, demonstrating that the photochemical reaction of organic precursors during daytime contributed more to the formation of SOC. Additionally, SOC/OC ratio was $48.7 \%$ in June, while relatively low ratios were observed in July and August for $40.6 \%$ and $41.2 \%$, respectively. The average temperatures of these months were $14.9,17.8$ and $18.2^{\circ} \mathrm{C}$, respectively, and low temperature during June was conducive to the condensation of semi-volatile matters onto aerosol particles. Such a relationship between SOC proportions and temperatures could be partially explained by the partitioning and accumulation of semi-volatile organic compounds (SVOC) to particle phase under low-temperature conditions, which accelerated the reaction of precursors to form SOC (Ji et al., 2018).

\section{Impacts of Cloud/fog Processing on SOA Formation}

Though clouds and fogs are favorable to remove atmospheric particulate matters and hence give rise to a decrease in aerosol concentrations, it has been reported that atmospheric aqueous-phase reaction of SVOC during cloud/fog events could be an effective formation pathway for SOA (De Haan et al., 2011).

Several field studies were conducted to investigate the influences of cloud and fog on SOA formation processing in the last few decades. Above all, the non-volatile organic compounds (NVOC) concentrations decreased significantly due to the efficient removal effect of cloud/fog, resulting in a large proportion of organic particles converted into $\mathrm{CCN}$ in droplets (Wang et al., 2011). In contrast to the fluctuation of NVOC, SVOC displayed an increasing tendency, which can be ascribed to the partitioning of organic gases and subsequent gas-phase oxidation products into droplets under the influence of large amounts of NVOC (Herckes et al., 2013). Such an absorption process could facilitate the aqueous-phase reaction of organic precursors in cloud/fog droplets, resulting in higher SOC concentrations during cloud/fog events.

Taking advantage of frequent clouds and fogs covering the summit of Mount Tai during sampling period, samples during a heavy cloud/fog event lasting about 24 hours from June 16 to 17 were selected to analyze the relationship between cloud/fog event and SOA formation. Fig. 3 presented the temporal variation of $\mathrm{OC}$ and SOC concentrations, $\mathrm{SOC} / \mathrm{OC}$ ratios and related species concentrations during this event. It could be observed that a 24-hour cloud and fog pollution broke out during the period between June 16 and June 17 , followed by a rain scavenging for several hours. SOC concentrations maintained a significant increasing trend as cloudy and foggy weather continued, and then the peak value was appeared at midday of June 17. Furthermore, the maximum SOC concentration observed at 12:00 on June 17 was $3.51 \mathrm{\mu g} \mathrm{m}^{-3}$, accounting for $50.3 \%$ of total OC mass concentration, which was much higher than the initial level (average of $1.94 \mu \mathrm{g} \mathrm{m}^{-3}$ with proportion of $40.4 \%$ ) before cloud/fog event, directly demonstrating the important role of aqueous-phase reaction in SOA formation and the accumulative effect of SOA during cloud/fog processing. However, this rising trend under cloud/fog effect in our study was lower than the result determined by the same method at a high-altitude mountain area located in Southern China and another observation conducted at Mount Tai in the summer of 2007 (Wang et al., 2012; Zhou et al., 2012;), indicating the differences in concentrations and formation characteristics of SOC during cloud/fog events in different geographic locations and years.

\section{Source Apportionment by PMF Model}

To better identify the emission sources and quantify their contributions, the PMF model was applied in this study. A total of eight carbonaceous species including OC1, OC2, OC3, OC4, EC1, EC2, EC3 and OPC were detected from samples and used as input data to PMF source apportionment model. Three to six factors were tested and a three-factor solution with good explained variation and explicable source profiles was selected as the most optimal result. Based on the source apportionment results of carbonaceous aerosols reported previously, four main emission sources including diesel vehicle exhaust, gasoline vehicle exhaust, biomass burning and coal combustion were identified in our study (Wang et al., 2017). The explained variation of these sources and the contributions of three factors to total carbon were presented in Figs. 4 and 5.

The chemical composition profile of factor 1 was dominated by EC2 and EC3, which were mainly generated from diesel vehicle exhaust emission (Cao et al., 2005), thus factor 1 was interpreted as diesel vehicle exhaust. Factor 2 was characterized by the high loading of $\mathrm{OC} 1$, which was suggested to be typical biomass marker (Shen et al., 2014). Additionally, Singh et al. (2015) also reported 


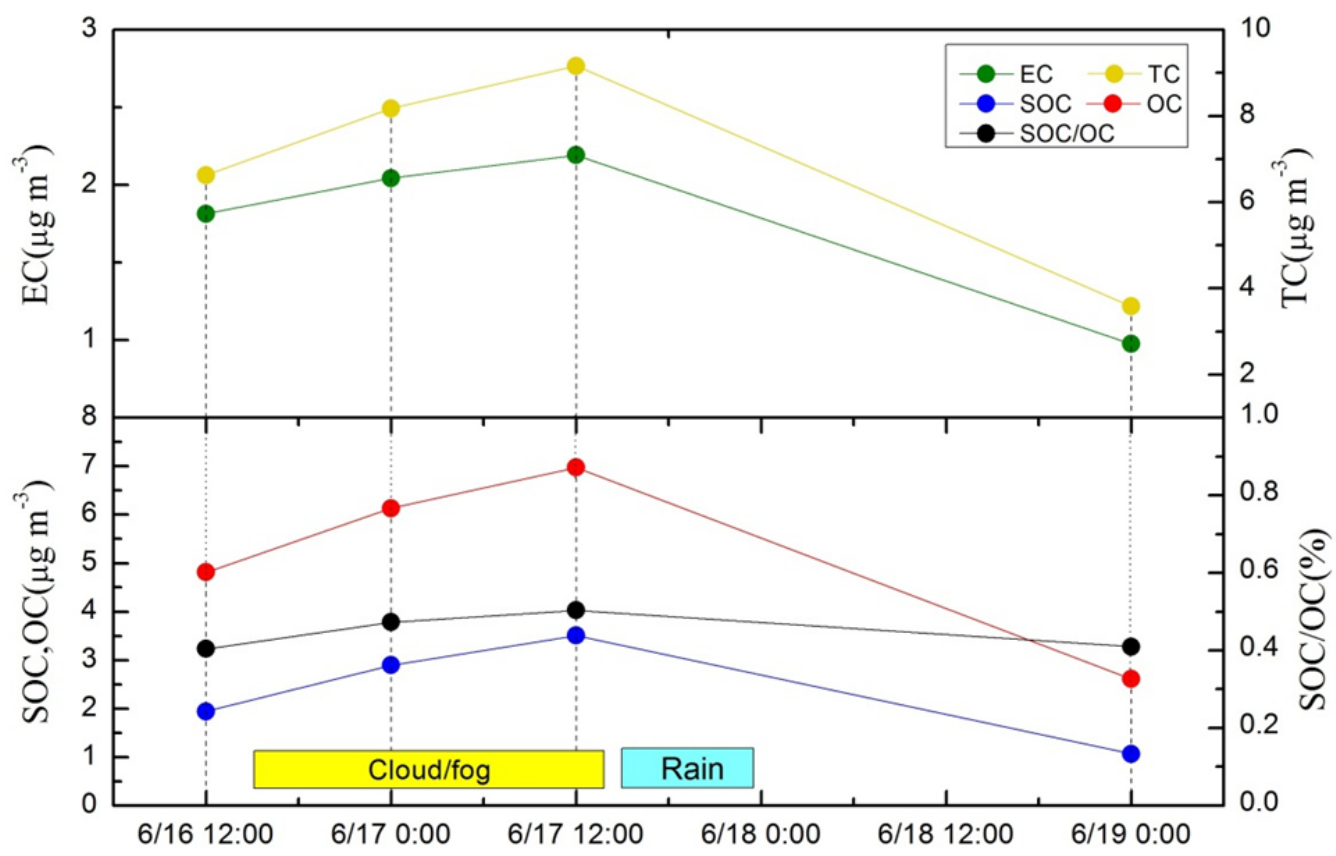

Fig. 3. Concentration time series of carbonaceous aerosols, and the proportion of SOC to OC during a heavy cloud/fog event from June 16 to 17 at Mount Tai.

that biomass burning was the major source of $\mathrm{OC} 1$, suggesting factor 2 could be inferred as biomass burning. Factor 3 showed the significant loadings of EC1, OC2 and OC4, followed by OPC and OC3. These species were mainly emitted from gasoline vehicle exhaust, and meanwhile OC2 and OPC were closely correlated to coal combustion (Li et al., 2012). Therefore, factor 3 was determined as the mixed source of gasoline vehicle exhaust and coal combustion.

Among these factors, factor 1 contributed significantly to carbonaceous aerosols, accounting for about $26.4 \%$. The contribution of factor 2 was $19.0 \%$, which was apparently higher than the result observed in non-harvest seasons (Cao et al., 2005). It was reported by the first national pollution source survey that Shandong was one of the biggest agricultural province in China, hence the elevated proportion of factor 2 was probably ascribed to the increase of open biomass burning (e.g., wheat straws burning) after the grain crop harvest during harvest season (from June to October in the North China Plain). Factor 3 exhibited the highest contribution $(54.5 \%)$ to total carbon in $\mathrm{PM}_{2.5}$, reflecting a dominance of this factor in total emissions. Moreover, the emission of fossil fuel combustion was defined as a combination of coal combustion and vehicle exhaust emission (i.e., the sum of factor 1 and factor 3 ) with extremely high contribution of $81.0 \%$, demonstrating that fossil fuel combustion was the major emission source of carbonaceous aerosols pollution occurred at Mount Tai.

\section{Regional Source Identification}

Regional sources and transport pattern of pollutants had considerable effects on air quality (Gong et al., 2018). In this present study, PSCF analysis was adopted to investigate the potential regional sources of carbonaceous species.
Fig. 6 provided the PSCF maps of eight carbonaceous species achieved by PSCF function module of TrajStat software, and different colors represented the contribution levels associated with the possibility of grid cells being a significant source.

As shown in maps, weak and low PSCF values were observed at sampling site and surrounding areas, suggesting that Mount Tai, as a background site, had relatively less regional pollution. Significant potential regional sources with higher PSCF values for most species (except OC2) were mainly distributed in BTH region (northwest of Mount Tai), illustrating that carbonaceous aerosols at Mount Tai were largely affected by the pollutants transported from this region. The BTH region, as one of the largest urban agglomerations in China, is a heavily polluted industrial areas with a large population, which contributed to the high level of industrial and traffic emissions, resulting in a massive transport of industrial pollutants and vehicle exhaustrelated pollutants to Mount Tai under the influence of northwest wind (Zhang et al., 2017). Meanwhile, considering the enhancement of biomass burning during harvest season, the long-range transport of pollutants generated from crop straw burning in BTH region was also a major contributor to carbonaceous aerosols at Mount Tai.

Except for BTH region, these carbonaceous species were also affected by long-range transport of carbonaceous aerosols from other regions. It was found in Fig. 6(a) that a small part of potential sources for OC1 were located in eastern Shandong. For the effects in Shandong province, the PMF result indicated that the crop straws burning in agricultural districts of Shandong played an important role in OC1 accumulations. Moreover, PSCF map of Fig. 6(b) suggested two source regions for $\mathrm{OC} 2$, northern Henan in the west and eastern Shandong in the east, which were 

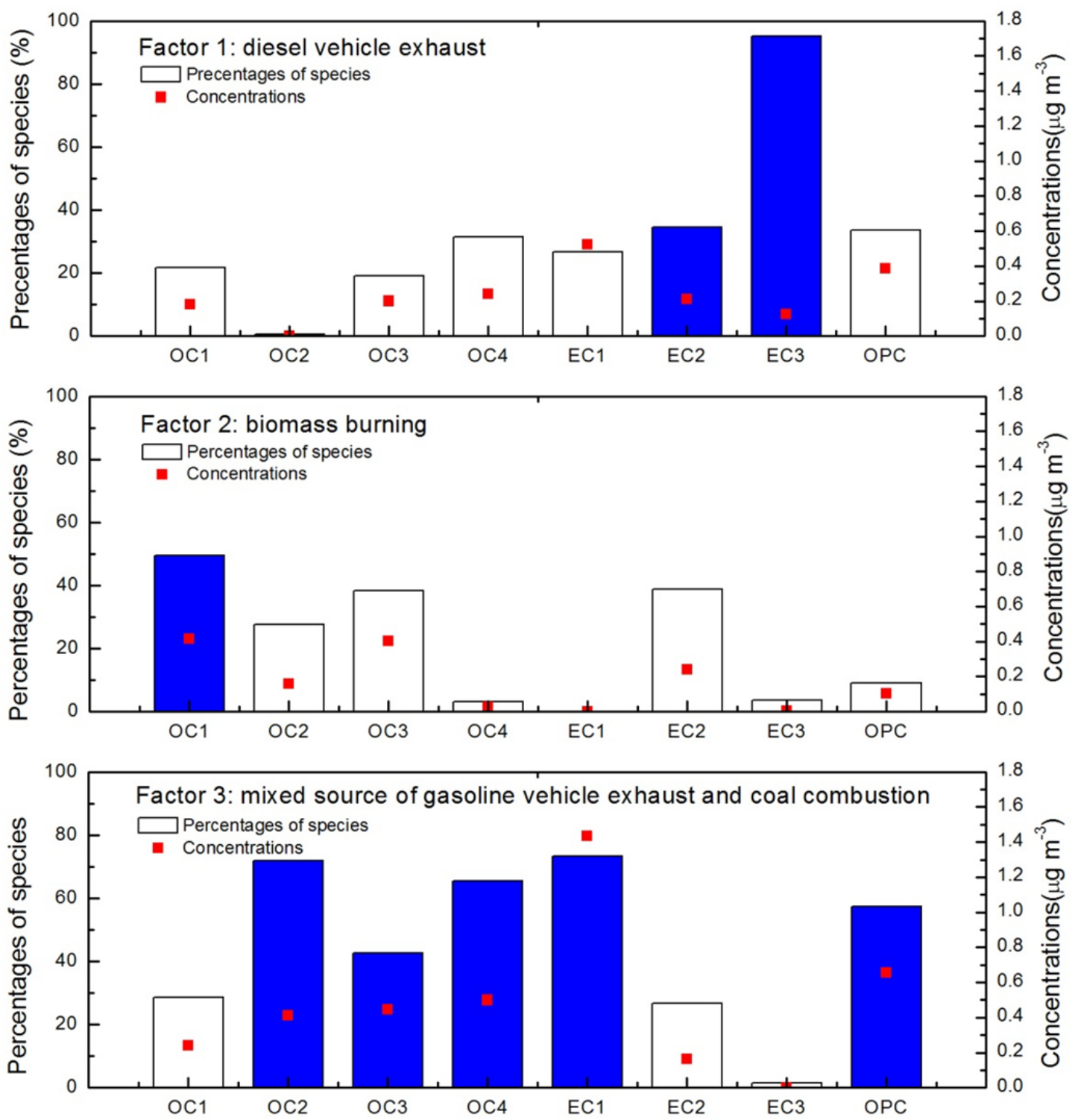

Fig. 4. Explained variation of the emission sources for carbonaceous species resolved by PMF during sampling period. Blue-filled bars represents the main fractions that can characterize each factor.

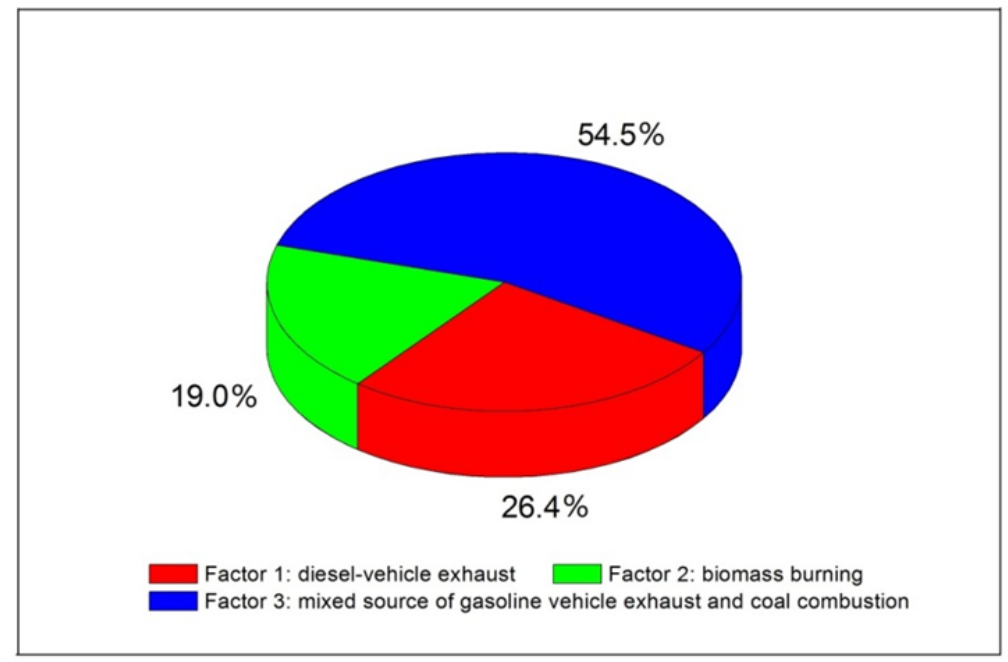

Fig. 5. Contributions of three emission sources to carbonaceous aerosols derived from PMF. 


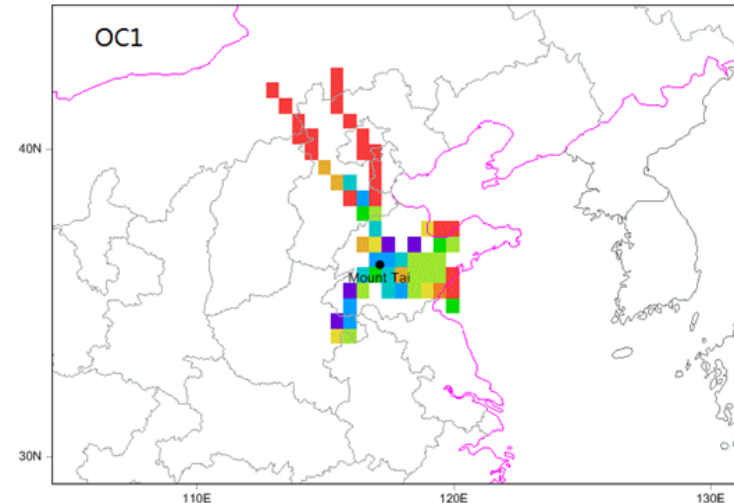

(a)

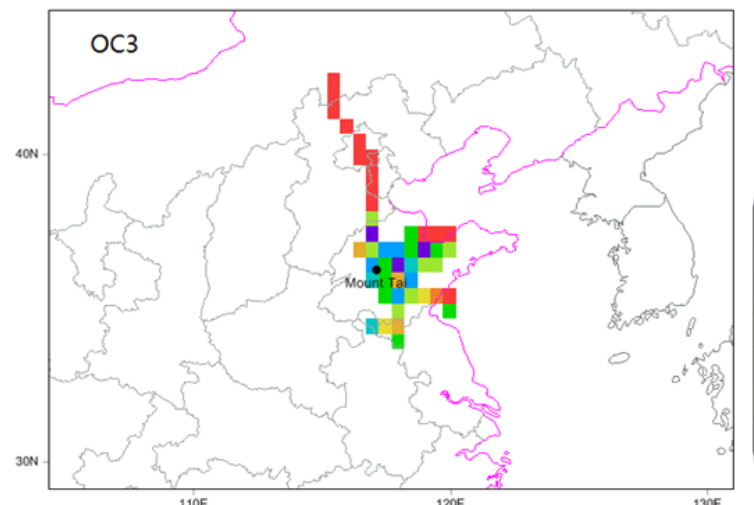

(c)

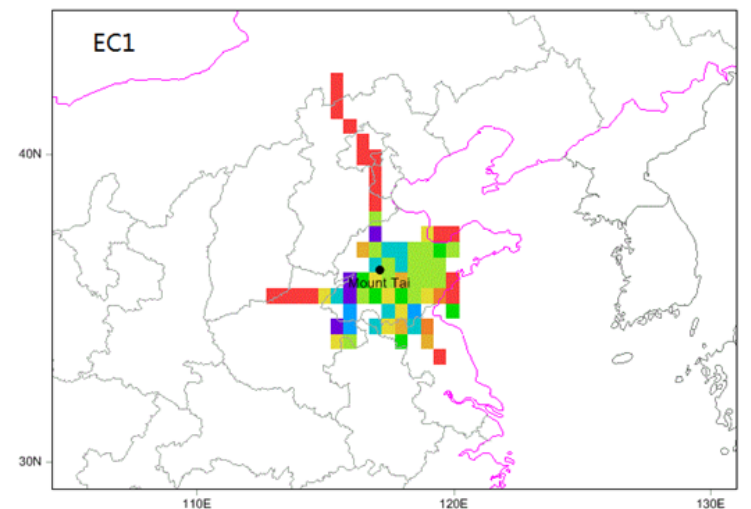

(e)

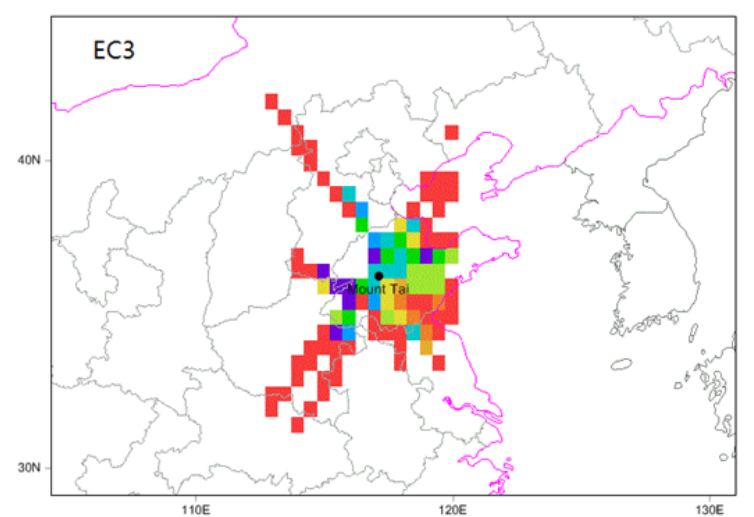

(g)

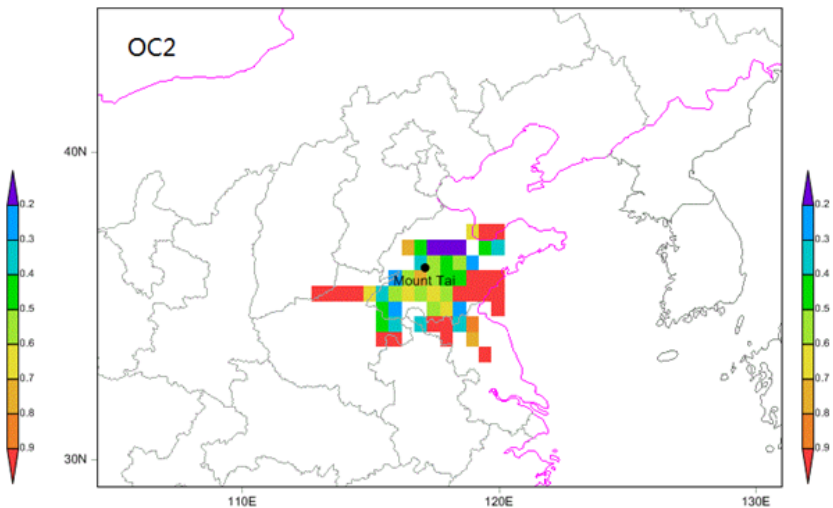

(b)

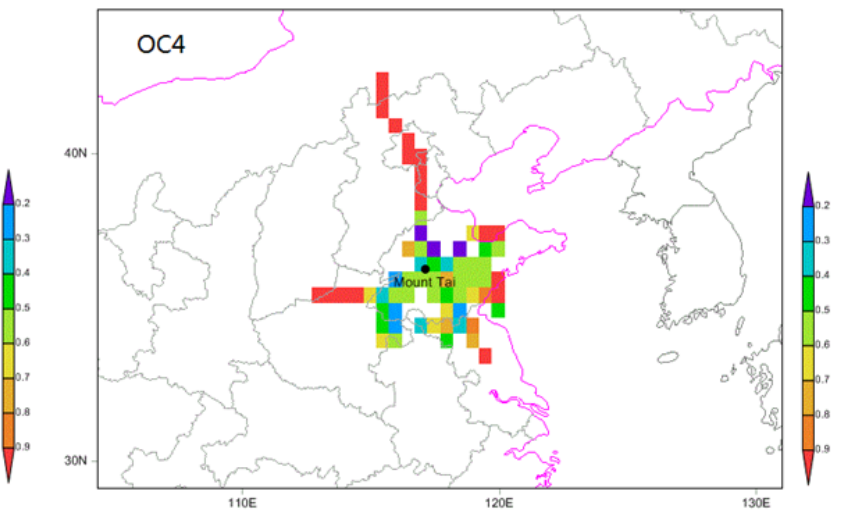

(d)

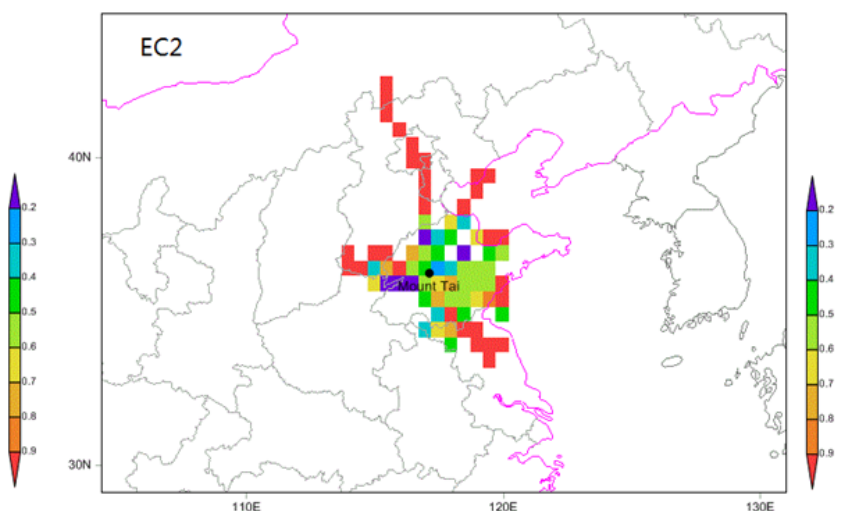

(f)

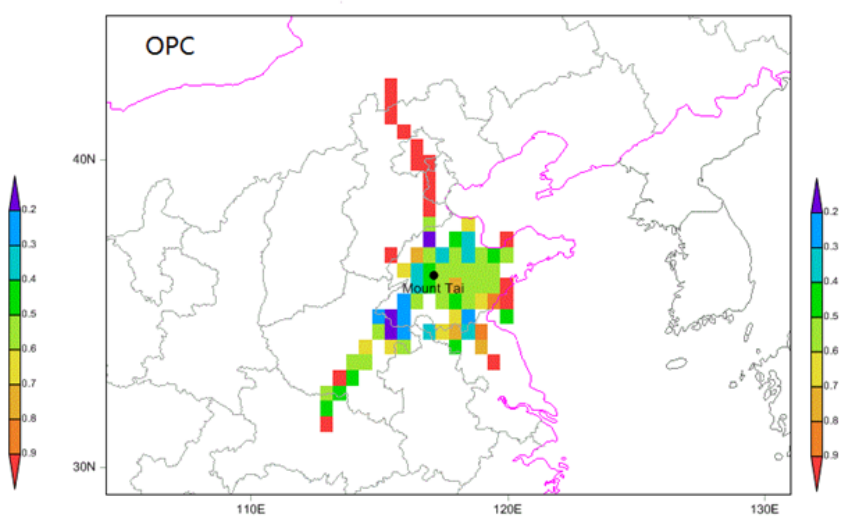

(h)

Fig. 6. The PSCF maps of carbonaceous species including (a) OC1, (b) OC2, (c) OC3, (d) OC4, (e) EC1, (f) EC2, (g) EC3 and (h) OPC at Mount Tai. 


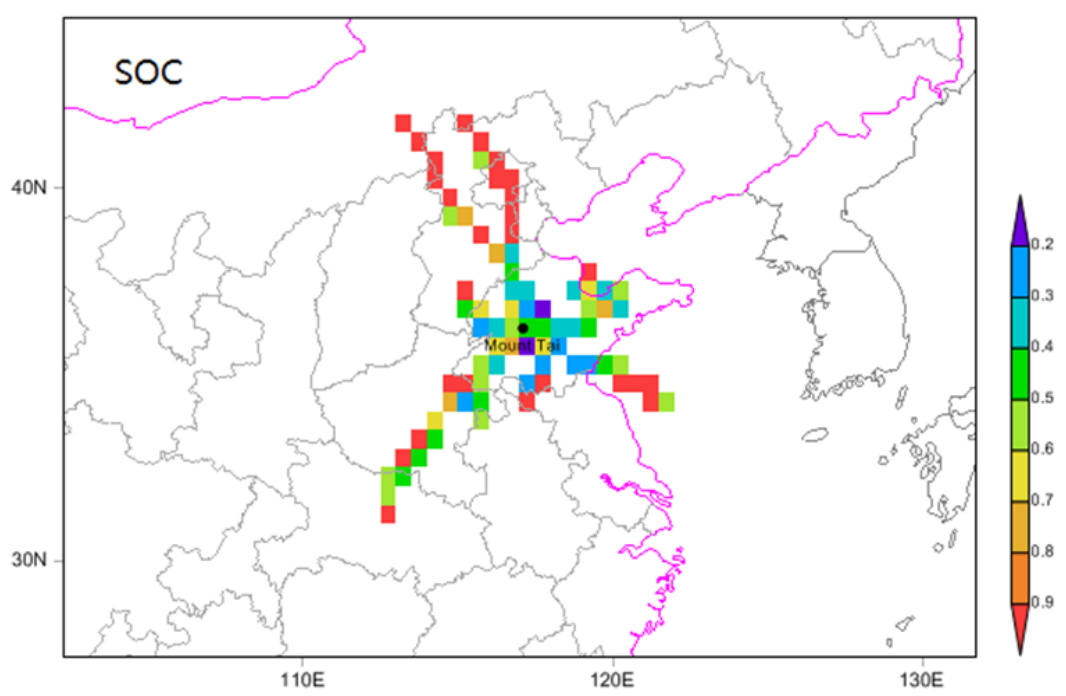

Fig. 7. The PSCF map of SOC at Mount Tai.

likely related to specific gasoline vehicle exhaust with relatively high loading of OC2 according to PMF analysis result. As depicted in Figs. 6(f)-6(g), the Bohai Sea and the Yellow Sea were found as the potential sources of EC2 and EC3, with high PSCF values exceeding 0.9. Considering that EC2 and EC3 were mainly emitted from diesel motor exhaust (mentioned in PMF section), it can be inferred that this PSCF result was attributed to the high emissions of diesel-powered ships on the sea.

It should be noted that the PSCF maps of motor vehicle exhaust-related species (OC2, OC4, EC1, EC2 and EC3) showed much wider distribution of regional sources than other species, covering BTH region, Henan province, Shandong province, Bohai Sea, Yellow Sea, as well as Jiangsu province in the southeast. Indeed, vehicle exhaust emission has become one of the most extensive regional sources of atmospheric pollution due to the high ownership and dramatic increase of motor vehicles over China, which is consistent with our result (Guo et al., 2016). For regional contribution of SOC, two high-potential sources were observed in BTH region and the Yellow Sea (Fig. 7). The traffic emission and ship emission in these regions could emit a large amount of volatile organic precursors, and then contributed significantly to SOC formation by photochemical reaction and/or aqueous-phase reaction.

\section{CONCLUSIONS}

In the present study, a field sampling of daily carbonaceous aerosols in $\mathrm{PM}_{2.5}$ were carried out at Mount Tai from June 15 to August 11, 2015, using a high-volume air sampler (HI-Q 7386). This paper presented the results about concentration variations, SOA formation and source analysis of carbonaceous aerosols, based on the values analyzed by an Organic/Elemental Carbon Analyzer (DRI model 2001) following the TOR protocol.

Daily concentrations of OC and EC during sampling campaign were $4.42 \pm 3.04$ and $1.58 \pm 0.92 \mu \mathrm{g} \mathrm{m}^{-3}$, with the range of $1.06-14.8$ and $0.31-3.83 \mu \mathrm{g} \mathrm{m}^{-3}$, accounting for $11.1 \%$ and $4.0 \%$ of $\mathrm{PM}_{2.5}$ concentration, respectively. OC and EC displayed significant weekly fluctuations. Higher concentrations were frequently observed under the influences of frequent human activities. The estimation of SOC was performed by EC-tracer method, and we found that SOC concentrations increased remarkably during cloud/fog events, confirming the important role of enhanced aqueous-phase reaction of precursors in cloud/fog droplets in SOC formation. Based on the results determined by PSCF analysis, eight carbonaceous species showed highpotential regional sources with higher PSCF values in the northwest, southwest and east coastal areas of Mount Tai. This regional source distribution was consistent with the distribution characteristics of emission sources for each species in PMF analysis, which highlighted three factors (diesel vehicle exhaust, biomass burning and mixed sources of gasoline vehicle exhaust and coal combustion) as main emission sources of carbonaceous species.

\section{ACKNOWLEDGMENTS}

We acknowledge the Mount Tai Meteorological Station for their support on the field study. This work was financially supported by the National Natural Science Foundation of China (41601548, 81602827, 21806158), Tianjin Municipal Education Commission Research Project (2017KJ244), Fundamental Research Funds of National Institute of Metrology, China (AKY1720), Training Program for Innovative Research Team in Tianjin Institutions of Higher Education (TD13-5021), Basic Research and Frontier Exploration Projects in Chongqing (Natural Science Foundation of Chongqing) (cstc2018jcyjAX0776) and Research Start-up Funding Project of Chongqing Technology and Business University (1756003).

\section{REFERENCES}

Boreddy, S.K.R., Kawamura, K., Okuzawa, K., Kanaya, Y. and Wang, Z.F. (2017). Temporal and diurnal variations 
of carbonaceous aerosols and major ions in biomass burning influenced aerosols over Mt. Tai in the North China Plain during MTX2006. Atmos. Environ. 154: 106-117.

Bressi, M., Sciare, J., Ghersi, V., Mihalopoulos, N., Petit, J.E., Nicolas, J.B., Moukhtar, S., Rosso, S., Féron, A. and Bonnaire, N. (2014). Sources and geographical origins of fine aerosols in Paris (France). Atmos. Chem. Phys. 14: 8813-8839.

Cao, J.J., Lee, S.C., Chow, J.C., Watson, J.G., Ho, K.F., Zhang, R.J., Jin, Z.D., Shen, Z.X., Chen, G.C. and Kang, Y.M. (2007). Spatial and seasonal distributions of carbonaceous aerosols over China. J. Geophys. Res. 112: D22S11.

Cao, J.J., Wu, F., Chow, J.C., Lee, S.C., Li, Y., Chen, S.W., An, Z.S., Fung, K.K., Watson, J.G., Zhu, C.S. and Liu, S.X. (2005). Characterization and source apportionment of atmospheric organic and elemental carbon during fall and winter of 2003 in Xi'an, China. Atmos. Chem. Phys. 5: 3127-3137.

Castro, L.M., Pio, C.A., Harrison, R.M. and Smith, D.J.T. (1999). Carbonaceous aerosol in urban and rural European atmospheres: estimation of secondary organic carbon concentrations. Atmos. Environ. 33: 2771-2781.

Chang, Y., Deng, C., Cao, F., Cao, C., Zou, Z., Liu, S., Lee, X., Li, J., Zhang, G. and Zhang, Y. (2017). Assessment of carbonaceous aerosols in Shanghai, China - Part 1: long-term evolution, seasonal variations, and meteorological effects. Atmos. Chem. Phys. 17: 9945-9964.

Chow, J.C., Watson, J.G., Mauderly, J.L., Costa, D.L., Wyzga, R.E., Vedal, S., Hidy, G.M., Altshuler, S.L., Marrack, D., Heuss, J.M., Wolff, G.T., Pope, C.A. and Dockery, D.W. (2006). Health effects of fine particulate air pollution: Lines that connect. J. Air Waste Manage. Assoc. 56: 1368-1380.

De Haan, D.O., Hawkins, L.N., Kononenko, J.A., Turley, J.J., Corrigan, A.L., Tolbert, M.A. and Jimenez, J.L. (2011). Formation of nitrogen-containing oligomers by methylglyoxal and amines in simulated evaporating cloud droplets. Environ. Sci. Technol. 45: 984-991.

Fan, Z.L., Chen, X.C., Lui, K.H., Ho, S.S.H., Cao, J.J., Lee, S.C., Huang, H. and Ho, K.F. (2017). Relationships between outdoor and personal exposure of carbonaceous species and polycyclic aromatic hydrocarbons (PAHs) in fine particulate matter $\left(\mathrm{PM}_{2.5}\right)$ at Hong Kong. Aerosol Air Qual. Res. 17: 666-679.

Gong, P., Wang, X., Sheng, J., Wang, H., Yuan, X., He, Y., Qian, Y. and Yao, T. (2018). Seasonal variations and sources of atmospheric polycyclic aromatic hydrocarbons and organochlorine compounds in a high-altitude city: Evidence from four-year observations. Environ. Pollut. 233: 1188-1197.

Grivas, G., Cheristanidis, S. and Chaloulakou, A. (2012). Elemental and organic carbon in the urban environment of Athens. Seasonal and diurnal variations and estimates of secondary organic carbon. Sci. Total Environ. 414: 535-545.

Guo, X.R., Fu, L.W., Ji, M.S., Lang, J.L., Chen, D.S. and
Cheng, S.Y. (2016). Scenario analysis to vehicular emission reduction in Beijing-Tianjin-Hebei (BTH) region, China. Environ. Pollut. 216: 470-479.

Harley, R.A. and Cass, G.R. (1995). Modeling the atmospheric concentrations of individual volatile organic compounds. Atmos. Environ. 29: 905-922.

Herckes, P., Valsaraj, K.T. and Collett, J.L. (2013). A review of observations of organic matter in fogs and clouds: Origin, processing and fate. Atmos. Res. 132133: 434-449.

Ji, D.S., Li, L., Pang, B., Xue, P., Wang, L.L., Wu, Y.F., Zhang, H.L. and Wang, Y.S. (2017). Characterization of black carbon in an urban-rural fringe area of Beijing. Environ. Pollut. 223: 524-534.

Ji, D.S., Yan, Y.C., Wang, Z.S., He, J., Liu, B.X., Sun, Y., Gao, M., Li, Y., Cao, W., Cui, Y., Hu, B., Xin, J.Y., Wang, L.L., Liu, Z.R., Tang, G.Q. and Wang, Y.S. (2018). Two-year continuous measurements of carbonaceous aerosols in urban Beijing, China: Temporal variations, characteristics and source analyses. Chemosphere 200: 191-200.

Koch, D. (2001). Transport and direct radiative forcing of carbonaceous and sulfate aerosols in the GISS GCM. $J$. Geophys. Res. 106: 20311-20332.

Li, J.X., Li, P.R., Yuan, L.A., Yin, Y., Wang, Z.Z., Li, J., Li, Y.A., Ren, G. and Cai, Z.X. (2017). Physical and optical properties of atmospheric aerosols in summer at a suburban site in North China. Aerosol Air Qual. Res. 17: 1474-1488.

Li, P.H., Han, B., Huo, J., Lu, B., Ding, X., Chen, L., Kong, S.F., Bai, Z.P. and Wang, B. (2012). Characterization, meteorological influences and source identification of carbonaceous aerosols during the autumn-winter period in Tianjin, China. Aerosol Air Qual. Res. 12: 283-294.

Li, P., Sato, K., Hasegawa, H., Huo, M.Q., Minoura, H., Inomata, Y., Take, N., Yuba, A., Futami, M., Takahashi, T. and Kotake, Y. (2018). Chemical characteristics and source apportionment of $\mathrm{PM}_{2.5}$ and long-range transport from northeast Asia continent to Niigata in eastern Japan. Aerosol Air Qual. Res. 18: 938-956.

Liang, D.N., Ma, X., Zhang, J.S., Liu, Z.J., Wu, J.H., Feng, Y.C. and Zhang, Y.F. (2017). Chemical analysis of particulate matter in the harvest period in an agricultural region of eastern China. Aerosol Air Qual. Res. 17: 2381-2389.

Liu, B.S., Zhang, J.Y., Wang, L., Liang, D.N., Cheng, Y., Wu, J.H., Bi, X.H., Feng, Y.C., Zhang, Y.F. and Yang, H.H. (2018). Characteristics and sources of the fine carbonaceous aerosols in Haikou, China. Atmos. Res. 199: 103-112.

Liu, J., Wang, Y., Le, P.H., Shou, Y.P., Li, T., Yang, M.M., Wang, L., Yue, J.J., Yi, X.L. and Guo, L.Q. (2017). Polycyclic aromatic hydrocarbons (PAHs) at high mountain site in north China: Concentration, Source and health risk assessment. Aerosol Air Qual. Res. 17: 28672877.

Manousakas, M., Papaefthymiou, H., Diapouli, E., Migliori, A., Karydas, A.G., Bogdanovic-Radovic, I. and Eleftheriadis, K. (2017). Assessment of $\mathrm{PM}_{2.5}$ sources 
and their corresponding level of uncertainty in a coastal urban area using EPA PMF 5.0 enhanced diagnostics. Sci. Total Environ. 574: 155-164.

Martinsson, J., Andersson, A., Sporre, M.K., Friberg, J., Kristensson, A., Swietlicki, E., Olsson, P.A. and Stenstrom, K.E. (2017). Evaluation of delta C-13 in carbonaceous aerosol source apportionment at a rural measurement site. Aerosol Air Qual. Res. 17: 20812094.

Mauderly, J.L. and Chow, J.C. (2008). Health effects of organic aerosols. Inhalation Toxicol. 20: 257-288.

Niu, Z., Wang, S., Chen, J., Zhang, F., Chen, X., He, C., Lin, L., Yin, L. and Xu, L. (2013). Source contributions to carbonaceous species in $\mathrm{PM}_{2.5}$ and their uncertainty analysis at typical urban, peri-urban and background sites in southeast China. Environ. Pollut. 181: 107-114.

Paatero, P. and Tapper, U. (1993). Analysis of different modes of factor analysis as least squares fit problems. Chemom. Intell. Lab. Syst. 18: 183-194.

Pandis, S.N., Harley, R.A., Cass, G.R. and Seinfeld, J.H. (1992). Secondary organic aerosol formation and transport. Atmos. Environ. 26a: 2269-2282.

Panicker, A.S., Aditi, R., Beig, G., Ali, K. and Solmon, F. (2018). Radiative forcing of carbonaceous aerosols over two urban environments in northern India. Aerosol Air Qual. Res. 18: 884-894.

Peng, X.L., Hao, Q.J., Wen, T.X., Ji, D.S., Liu, Z.R., Wang, Y.S., He, X.H., Li, X.X. and Jiang, C.S. (2018). Characteristics of organic carbon and elemental carbon in atmospheric aerosols in the urban area in Beibei, a suburb of Chongqing. Aerosol Air Qual. Res. 18: 27642774.

Plaza, J., Artíñano, B., Salvador, P., Gómez-Moreno, F.J., Pujadas, M. and Pio, C.A. (2011). Short-term secondary organic carbon estimations with a modified OC/EC primary ratio method at a suburban site in Madrid (Spain). Atmos. Environ. 45: 2496-2506.

Pongpiachan, S., Kositanont, C., Palakun, J., Liu, S., Ho, K.F. and Cao, J. (2015). Effects of day-of-week trends and vehicle types on $\mathrm{PM}_{2.5}$-bounded carbonaceous compositions. Sci. Total Environ. 532: 484-494.

Ram, K., Sarin, M.M. and Hegde, P. (2008). Atmospheric abundances of primary and secondary carbonaceous species at two high-altitude sites in India: Sources and temporal variability. Atmos. Environ. 42: 6785-6796.

Rastogi, N., Singh, A., Sarin, M.M. and Singh, D. (2016). Temporal variability of primary and secondary aerosols over northern India: Impact of biomass burning emissions. Atmos. Environ. 125: 396-403.

Shen, Z.X., Cao, J.J., Zhang, L.M., Liu, L., Zhang, Q., Li, J.J., Han, Y.M., Zhu, C.S., Zhao, Z.Z. and Liu, S.X. (2014). Day-night differences and seasonal variations of chemical species in $\mathrm{PM}_{10}$ over Xi'an, northwest China. Environ. Sci. Pollut. 21: 3697-3705.

Singh, R., Kulshrestha, M.J., Kumar, B. and Chandra, S. (2015). Impact of anthropogenic emissions and open biomass burning on carbonaceous aerosols in urban and rural environments of Indo-Gangetic Plain. Air Qual. Atmos. Health 9: 809-822.
Stone, E.A., Snyder, D.C., Sheesley, R.J., Sullivan, A.P., Weber, R.J. and Schauer, J.J. (2008). Source apportionment of fine organic aerosol in Mexico City during the MILAGRO experiment 2006. Atmos. Chem. Phys. 8: 1249-1259.

Sunder Raman, R., Hopke, P.K. and Holsen, T.M. (2008). Carbonaceous aerosol at two rural locations in New York State: Characterization and behavior. J. Geophys. Res. 113: D12202.

Thuy, N.T.T., Dung, N.T., Sekiguchi, K., Thuy, L.B., Hien, N.T.T. and Yamaguchi, R. (2018). Mass concentrations and carbonaceous compositions of $\mathrm{PM}_{0.1}, \mathrm{PM}_{2.5}$, and $\mathrm{PM}_{10}$ at urban locations in Hanoi, Vietnam. Aerosol Air Qual. Res. 18: 1591-1605.

Turpin, B.J. and Huntzicker, J.J. (1991). Secondary formation of organic aerosol in the Los Angeles basin: A descriptive analysis of organic and elemental carbon concentrations. Atmos. Environ. 25: 207-215.

Turpin, B.J., Saxena, P. and Andrews, E. (2000). Measuring and simulating particulate organics in the atmosphere: Problems and prospects. Atmos. Environ. 34: 2983-3013.

Villalobos, A.M., Barraza, F., Jorquera, H. and Schauer, J.J. (2015). Chemical speciation and source apportionment of fine particulate matter in Santiago, Chile, 2013. Sci. Total Environ. 512: 133-142.

Wang, Q., Jiang, N., Yin, S., Li, X., Yu, F., Guo, Y. and Zhang, R. (2017). Carbonaceous species in $\mathrm{PM}_{2.5}$ and $\mathrm{PM}_{10}$ in urban area of Zhengzhou in China: Seasonal variations and source apportionment. Atmos. Res. 191: $1-11$.

Wang, Z., Wang, T., Gao, R., Xue, L.K., Guo, J., Zhou, Y., Nie, W., Wang, X.F., Xu, P.J., Gao, J.A., Zhou, X.H., Wang, W.X. and Zhang, Q.Z. (2011). Source and variation of carbonaceous aerosols at Mount Tai, North China: Results from a semi-continuous instrument. Atmos. Environ. 45: 1655-1667.

Wang, Z., Wang, T., Guo, J., Gao, R., Xue, L.K., Zhang, J.M., Zhou, Y., Zhou, X.H., Zhang, Q.Z. and Wang, W.X. (2012). Formation of secondary organic carbon and cloud impact on carbonaceous aerosols at Mount Tai, North China. Atmos. Environ. 46: 516-527.

Xu, J., Peng, X., Guo, C.S., Xu, J., Lin, H.X., Shi, G.L., Lv, J.P., Zhang, Y., Feng, Y.C. and Tysklind, M. (2016). Sediment PAH source apportionment in the Liaohe River using the ME2 approach: A comparison to the PMF model. Sci. Total Environ. 553: 164-171.

Xu, J., Wang, Q.Z., Deng, C.R., McNeill, V.F., Fankhauser, A., Wang, F.W., Zheng, X.J., Shen, J.D., Huang, K. and Zhuang, G.S. (2018). Insights into the characteristics and sources of primary and secondary organic carbon: High time resolution observation in urban Shanghai. Environ. Pollut. 233: 1177-1187.

Yao, L., Yang, L., Chen, J., Wang, X., Xue, L., Li, W., Sui, X., Wen, L., Chi, J., Zhu, Y., Zhang, J., Xu, C., Zhu, T. and Wang, W. (2016). Characteristics of carbonaceous aerosols: Impact of biomass burning and secondary formation in summertime in a rural area of the North China Plain. Sci. Total Environ. 557-558: 520-530.

Youn, J.S., Wang, Z., Wonaschutz, A., Arellano, A., 
Betterton, E.A. and Sorooshian, A. (2013). Evidence of aqueous secondary organic aerosol formation from biogenic emissions in the North American Sonoran Desert. Geophys. Res. Lett. 40: 3468-3472.

Yu, X.Y., Cary, R.A. and Laulainen, N.S. (2009). Primary and secondary organic carbon downwind of Mexico City. Atmos. Chem. Phys. 9: 6793-6814.

Zhang, J., Tong, L., Huang, Z., Zhang, H., He, M., Dai, X., Zheng, J. and Xiao, H. (2018). Seasonal variation and size distributions of water-soluble inorganic ions and carbonaceous aerosols at a coastal site in Ningbo, China. Sci. Total Environ. 639: 793-803.

Zhang, Q., Streets, D.G., Carmichael, G.R., He, K.B., Huo, H., Kannari, A., Klimont, Z., Park, I.S., Reddy, S., Fu, J.S., Chen, D., Duan, L., Lei, Y., Wang, L.T. and Yao, Z.L. (2009). Asian emissions in 2006 for the NASA INTEX-B mission. Atmos. Chem. Phys. 9: 5131-5153.

Zhang, Y.L., Zhu, B., Gao, J.H., Kang, H.Q., Yang, P., Wang, L.L. and Zhang, J.K. (2017). The source apportionment of primary $\mathrm{PM}_{2.5}$ in an aerosol pollution event over Beijing-Tianjin-Hebei region using WRF-Chem, China.
Aerosol Air Qual. Res. 17: 2966-2980.

Zhang, Y.M., Zhang, X.Y., Sun, J.Y., Hu, G.Y., Shen, X.J., Wang, Y.Q., Wang, T.T., Wang, D.Z. and Zhao, Y. (2014). Chemical composition and mass size distribution of $\mathrm{PM}_{1}$ at an elevated site in central east China. Atmos. Chem. Phys. 14: 12237-12249.

Zhao, P.S., Dong, F., Yang, Y.D., He, D., Zhao, X.J., Zhang, W.Z., Yao, Q. and Liu, H.Y. (2013). Characteristics of carbonaceous aerosol in the region of Beijing, Tianjin, and Hebei, China. Atmos. Environ. 71: 389-398.

Zhou, S.Z., Wang, Z., Gao, R., Xue, L.K., Yuan, C., Wang, T., Gao, X.M., Wang, X.F., Nie, W., Xu, Z., Zhang, Q.Z. and Wang, W.X. (2012). Formation of secondary organic carbon and long-range transport of carbonaceous aerosols at Mount Heng in South China. Atmos. Environ. 63: 203-212.
Received for review, June 23, 2019

Revised, July 17, 2019

Accepted, July 17, 2019 